\title{
PENGEMBANGAN KETERAMPILAN DAN KEMAMPUAN GURU SMKN 2 KOTA TEGAL DALAM MELAKUKAN PENELITIAN DAN PEMBUATAN KARYA ILMIAH
}

\author{
Dairoh $^{1}$, Slamet Wiyono ${ }^{2}$, Nurul Renaningtias ${ }^{3}$ \\ ${ }^{1,2,3}$ DIV Teknik Informatika, Politeknik Harapan Bersama Tegal \\ ${ }^{1}$ zaroh31@yahoo.co.id, ${ }^{2}$ slamet2wiyono@gmail.com, ${ }^{3}$ renaningtiasnurul@gmail.com
}

\begin{abstract}
Abstrak
Untuk meningkatkan profesionalisme seorang guru maka diwajibkan adanya pengembangan keprofesian yang berkelanjutan untuk meningkatkan kompetensi Guru, seperti halnya guru-guru SMK Negeri 2 Kota Tegal dimana salah satu diantaranya adalah publikasi karya ilmiah penelitian. Permasalahan yang terjadi di sekolah tersebut adalah tingkat kepedulian guru terhadap kegiatan penelitian masih rendah dan masih lemahnya tingkat kemampuan dan pemahaman guru dalam melakukan sebuah penelitian terlebih metodologi penelitian khususnya penelitian tindakan kelas (PTK) untuk menghasilkan sebuah karya ilmiah, sehingga berdampak pada lambatnya proses kenaikan golongan jabatan fungsional guru, selain itu masih banyak guru sekolah yang belum memahami terkait tata cara menulis sebuah karya ilmiah penelitian. Tujuan pengabdian ini adalah untuk dapat meningkatkan pengetahuan dan keterampilan guru terhadap suatu penelitian dan pembuatan artikel yang ilmiah sehingga sesuai dengan standar sebagai upaya peningkatan kompetensi guru. Metode kegiatan yang digunakan adalah dengan metode pelatihan berupa workshop yang dikemas sehingga materi yang disampaikan dapat diterima oleh para peserta kegiatan yang keseluruhan adalah guru sekolah. Hasil dari kegiatan pelatihan didapatkan bahwa terjadi peningkatan pengetahuan dan kompetensi peserta untuk mengatasi permasalahan yang dihadapi yaitu terkait dengan jabatan fungsional guru, metode penelitian dan pembuatan artikel ilmiah penelitian.
\end{abstract}

Kata Kunci: pelatihan, jabatan fungsional, penelitian tindakan kelas, artikel ilmiah

\section{PENDAHULUAN}

Saat ini tugas utama Guru adalah mendidik, mengajar, membimbing, mengarahkan, melatih, menilai dan mengevaluasi peserta didik pada pendidikan anak baik itu usia dini, pendidikan dasar maupun pendidikan menengah (Kamiludin and Suryaman, 2017; Alvarado and Bretones, 2018). Untuk meningkatkan profesionalisme guru, maka diwajibkan adanya pengembangan keprofesian yang berkelanjutan untuk meningkatkan kompetensi Guru tersebut (Susanto, 2018). Kompetensi Guru tersebut diantaranya adalah kompetensi pedagogik, kompetensi kepribadian, sosial, dan professional. Sebagai tolak ukur jabatan atau pangkat seorang Guru maka dikenal dengan nama jabatan fungsional, dimana jabatan tersebut melekat kepada Guru setelah memenuhi persyaratan-persyaratan yang telah ditentukan, untuk 
mendapatkan jenjang jabatan tersebut maka seorang Guru harus mengikuti program pengembangan keprofesian berkelanjutan (Tanama, Bafadal and Degeng, 2016).

Pengembangan keprofesian berkelanjutan adalah pengembangan kompetensi guru yang dilaksanakan sesuai dengan kebutuhan, bertahap, berkelanjutan untuk meningkatkan profesionalitasnya dalam upaya membuat sebuah perubahan keberhasilan siswa (Djunaidi, 2018). Guru wajib melaksanakan kegiatan pengembangan keprofesian berkelanjutan, yaitu pengembangan diri, publikasi ilmiah, dan/atau pengembangan karya inovatif (Sukmawati and Herawan, 2017). Khusus pada bidang publikasi ilmiah, termasuk didalamnya adalah publikasi ilmiah hasil penelitian atau gagasan inovatif pada bidang pendidikan formal, dan publikasi buku teks pelajaran, buku pengayaan dan pedoman guru (Wahab, 2017). Disisi lain, dalam sebuah proses pembuatan suatau karya ilmiah ketika Guru ingin mempublikasikannya dalam jurnal penelitian, maka saat ini hampir semua penerbit jurnal menggunakan pengembangan sistem jurnal elektronik berbasis Open Journal System (OJS) sebagai media proses penerbitannya (Chrisnanto, 2013).

Pada proses peningkatan kompetensi Guru pada setiap tingkatan satuan pendidikan, khususnya Guru SMK harus mempunyai kemampuan lebih dalam bidangnya terlebih apabila Guru tersebut telah tersertifikasi sehingga guru yang merupakan bagian dari salah satu faktor yang mempengaruhi keberhasilan pendidikan mempunyai kinerja yang lebih baik (Ramli and Jalinus, 2013). SMK Negeri 2 Kota Tegal merupakan salah satu institusi tingkat satuan pendidikan yang berada di wilayah Kota Tegal dengan konsentrasi pendidikan Vokasi dalam proses pembelajarannya. Saat ini mempunyai jumlah Guru sebanyak 52 orang dengan berbagai jenjang golongan dan jabatan fungsional.

Salah satu jenis penelitian yang sering dipublikasikan oleh Guru adalah penelitian tindakan kelas (PTK) yaitu penelitian dengan melakukan tindakan yang dilakukan oleh guru didalam kelasnya sendiri melalui refleksi diri, dengan tujuan untuk memperbaiki kinerjanya sebagai guru (Sanjaya, 2010). Tujuan akhir pelaksanaan PTK adalah untuk meningkatkan kualitas praktik pembelajaran di sekolah, relevansi pendidikan, mutu hasil pendidikan dan efisiensi pengelolaan pendidikan (Basrowi and Suwandi, 2008). Dengan melaksanakan kegiatan PTK ini guru seyogyanya sudah dapat bahan dalam pembuatan sebuah karya ilmiah penelitian. Melihat keadaan yang terjadi di SMK Negeri 2 Kota Tegal, dimana banyak para guru yang selama ini tidak melakukan kegiatan penelitian dikarenakan kurangnya pengetahuan serta keterampilan guru dalam melaksanakan penelitian dan membuat sebuah karya ilmiah yang baik dengan terlebih dahulu melakukan penelitian salah satunya adalah Penelitian Tindakan Kelas (PTK). Media publikasi yang digunakan hanya sebagai pelaporan penelitian saja, hal ini dilakukan cukup hanya dengan mempresentasikannya dalam sebuah kelompok studi guru yang bersangkutan seperti kelompok disksusi MGMP. 
Sebenarnya SMK Negeri 2 Tegal memiliki beberapa kemampuan dan keunggulan yang dimilikinya untuk dapat dijadikan sebagai pendukung untuk mengatasi permasalahan prioritas yang dihadapi. Adapun kemampuan yang dimiliki oleh SMKN 2 Kota Tegal adalah fasilitas sarana dan prasarana sekolah sudah memadai dan cukup baik untuk mendukung. Permasalahan yang saat dihadapi oleh SMK Negeri 2 Kota Tegal adalah masih lemahnya kemampuan dan keterampilan guru dalam melakukan sebuah penelitian dan menulis sebuah karya ilmiah sehingga berdampak pada lambatnya proses kenaikan golongan jabatan fungsional Guru. Saat ini yang terjadi di SMK Negeri 2 Tegal adalah Guru masih memandang bahwa kegiatan penelitian dan penulisan sebuah karya ilmiah dipandang sebagai kegiatan yang belum penting karena kenyataannya dalam proses belajar mengajar di sekolah dapat berjalan lancar tanpa penelitian. Penelitian tindakan kelas (PTK) atau classroom action research adalah penelitian dengan melakukan tindakan yang dilakukan oleh guru didalam kelasnya sendiri melalui refleksi diri, dengan tujuan untuk memperbaiki kinerjanya sebagai guru (Sanjaya, 2010).

Berdasarkan permasalahan yang menjadi fokus skala prioritas yang telah disepakati bersama antara tim pengusul PKM dan mitra dalam hal ini adalah SMKN 2 Kota Tegal, maka solusi yang ditawarkan adalah: (1) Pelatihan upgrading Pengembangan Keprofesian Berkelanjutan $(\mathrm{PKB})$ bagi Guru, untuk memberikan pengatahuan dan pemahaman terkait kegiatan pengembangan keprofesian berkelanjutan sebagai prasyarat untuk kenaikan Jabatan Fungsional Guru; (2) Workshop Penelitian Tindakan Kelas (PTK) bagi guru yang berfokus pada konsep dan metodologi dalam proses pelaksanaan penelitian PTK dengan analisis data berbasis komputerisasi; (3) Workshop serta pendampingan penulisan karya ilmiah untuk publikasi jurnal nasional dan jurnal nasional terakreditasi.

Target luaran pada kegiatan ini dintaranya adalah: (1) Meningkatnya kesadaran peserta kegiatan untuk keinginan dan motivasi untuk segera mengajukan pengusulan jabatan fungsional guru dan mampu mempersiapkan syarat-syarat untuk kenaikan pangkat maksimal dalam 2 tahun kedepan; (2) Meningkatnya pengetahuan guru di SMKN 2 Kota Tegal dan mampu melakukan proses perhitungan penetapan angka kredit untuk pengusulan jabatan fungsional; (3) Meningkatnya keterampilan mitra untuk mampu melaksanakan kegiatan penelitian Tindakan Kelas (PTK) dengan baik; (4) Meningkatkan keterampilan peserta kegiatan (Guru) untuk membuat sebuah artikel karya ilmiah maksimal 1 tahun kedepan persiapan dan dipublikasikan pada jurnal Nasional. 


\section{METODE}

1. Tempat Pelaksanaan dan Peserta

Kegiatan pengabdian dilaksanakan di SMKN 2 Kota Tegal di Jln Wisanggeni No.1 Kejambon Tegal Timur Kota Tegal. Pelaksanaan kegiatan dilaksanakan dalam beberapa tahap kegiatan yang dilaksanakan pada bulan bulan Mei s.d Juni 2019 dengan waktu pelaksanaan mulai jam 08.00 s.d 16.00 WIB. Peserta yang mengikuti kegiatan PKM adalah Guru-guru SMKN 2 Kota dengn latar belakang pendidikan yang berebda sesuai dengan mata pelajaran yang diajarkan dengan jumlah peserta ynag mengikuti kegiatan adalah berjumlah 50 orang.

\section{Tahapan Kegiatan}

Untuk menyelesaikan permasalahan yang menjadi prioritas utama, tahapan-tahapan yang dilakukan adalah: (1) Melakukan analisis permasalahan dan survey lokasi, pada tahapan ini dilakukan analisis mengenai keadaan mitra dari berbagai aspek sehingga merumuskan sebuah permasalahan yang harus segera diselesaikan. Dari hasil analisis diputuskan yang akan menjadi objek dari permasalahan tersebut adalah sumber daya dari mitra, yaitu Guru; Merumuskan permasalahan prioritas, pada tahapan ini didapatkan 4 (empat) permasalahan prioritas yang dihasilkan sesuai kesepakatan bersama; (3) Merumuskan solusi penyelesaian masalah, solusi yang didapatkan setelah terdapat kesepakatan adalah dilakukannya berbagai upaya pelatihan baik itu berupa workshop dan pelatihan, Diklat, serta pendampingan bagi para Guru; (4) Menjabarkan target luaran dari setiap solusi, pada tahapan ini dihasilkan targettarget luaran yaitu meningkatnya pengetahuan dan motivasi untuk melakukan pengusulan kenaikan jabatan fungsional, meningkatnya Kemampuan kompetensi Guru Dalam Membuat karya ilmiah hasil penelitian berbasiskan Teknologi Informasi.

\section{Metode Pelaksanan Kegiatan}

Pada pelaksanaan PKM dilakukan dengan menggunakan metode pelatihan dan training berupa workshop serta pendampingan dengan pendekatan menggunakan Metode pendekatan learning by doing dengan metode pembelajaran orang dewasa. Untuk melihat sejauh mana tingkat keberhasilan pelatihan yang telah bldiberikan dapat diikuti dan dipahami oleh para peserta pelatihan, maka evaluasi pre-test dan post-test dilakukan. Hal ini untuk melihat sejauh mana peserta pelatihan dapat menerima setiap materi yang disampaikan oleh fasilitator. Untuk melihat sejauhmana kebermanfaatan kegiatan maka dilakukan penyebaran 
questioner kepada para peserta kegiatan terkait dengan evaluasi pelaksanaan kegiatan dari sudut pandang peserta kegiatan.

\section{HASIL DAN PEMBAHASAN}

Dalam mengatasi permasalahan yang telah didapatkan dari mitra, pelaksanaan implementasi solusi yang dilakukan adalah mengadakan beberapa kegiatan workshop pelatihan, diantaranya adalah pelatihan peningkatan pemahaman mengenai jabatan fungsional guru, pelatihan peningkatan kemampuan dalam penelitian tindakan kelas, dan pelatihan kemampuan dalam membuat sebuah artikel ilmiah.

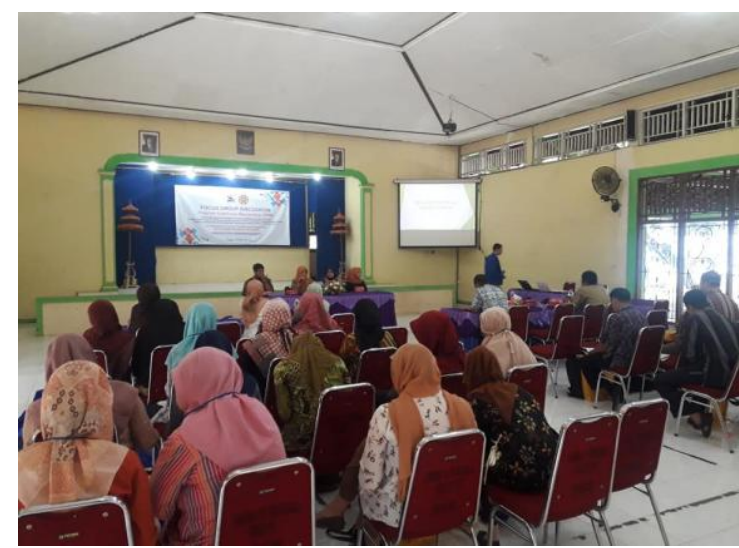

Gambar 1 Pelatihan Jabatan Fungsional

Sebagai implementasi bagian dari solusi yang disusulkan adalah sebuah pelatihan terkait dengan pemahaman guru dalam peningkatan jabatan fungsional, diperlihatkan pada gambar 1. Pada pelatihan ini diberikan update mengenai sistem penilaian terbaru dalam memperoleh jabatan fungsional beserta kebijakan-kebijakan yang terbaru sehingga peserta kegiatan dalam hal ini guru dapat memahami serta pengetahuan mengenai jabatan fungsional meningkat, salah satunya adalah pemahaman mengenai adanya artikel ilmiah sebagai salah satu point penilaian kenaikan jabatan fungsional.

Setelah pemahaman guru terhadap jabatan fungsional ini meningkat, maka selanjutnya ada memberikan pelatihan yang terkait dengan penelitian guru, salah satunya dalah peneilitian tindakan kelas. Pada pelatihan ini peserta kegiatan diberikan mater-materi terkait dengan matodologi penelitian PTK yang semestinya beserta luaran yang akan dihasilkan dari penelitian tersebut yaitu artikel ilmiah yang diterbitkan pada jurnal nasional, kegiatan diperlihatkan pada Gambar 2. 


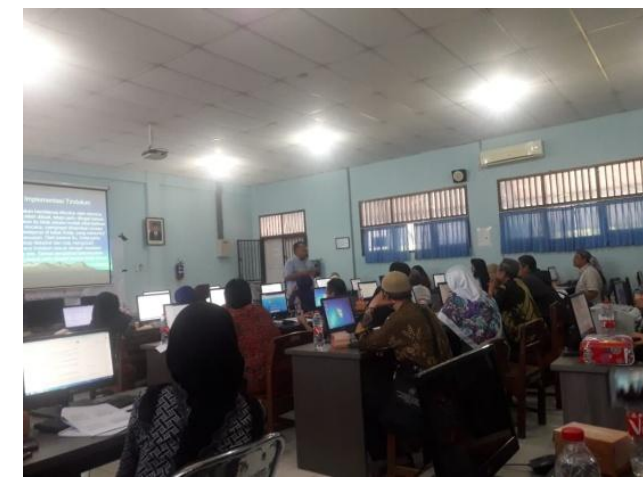

Gambar 2 Pelatihan Penelitian PTK

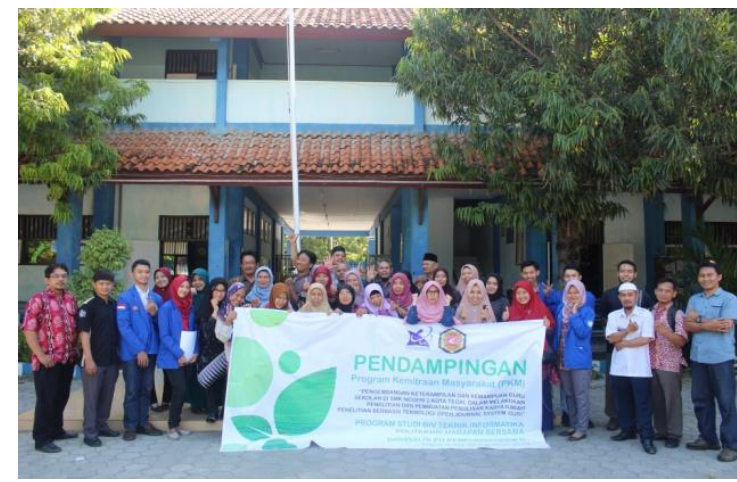

Gambar 3 Pendampingan kegiatan PKM

Pelatihan yang dilakukan sesuai dengan jadwal yang ditentukan belum sesuai dengan yang diinginkan, sehingga proses pendampingan terus dilakukan sesuai dengan batas waktu yang ditentukan yaitu selama satu periode masa pelaksanan PKM, sehingga proses pendampingan selain oleh Tim PKM dalam hal ini dilibatkan juga mahasiswa sebagai pendamping teknis pembuatan artikel secara terkomputeriasi karena berbasis teknologi informasi, kegiatan pendampingan seperti diperlihatkan pada Gambar 3.

\section{Evaluasi Kegiatan PKM}

Untuk mengukur sejauhmana tingkat keberhasilan kegiatan yang dilaksanakan, berdasarkan hasil qusioner yang telah disebar kepada para peserta kegiatan. Penilaian dilakukan dengan menggunakan nilai grid sebagai berikut: 1 = "Sangat tidak setuju", 2 = "Tidak Setuju", 3 = "cukup", 4 = "Setuju", dan 5 = "Sangat setuju".

Berdasarkan responden yang masuk, dari 32 responden peserta didapatkan hasil penilaian yang diperlihatkan pada Gambar 4 .

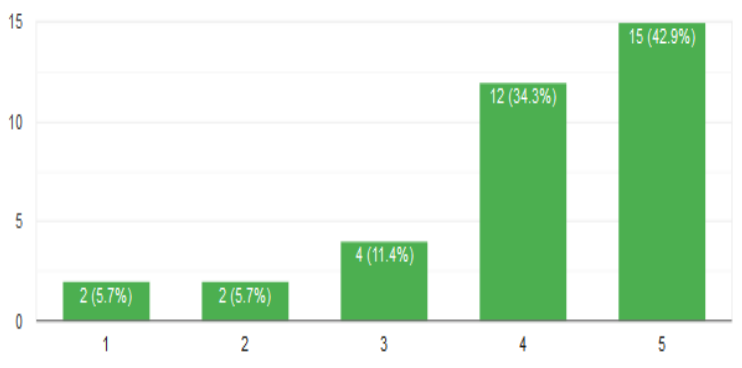

Gambar 4 Evaluasi kegiatan

Berdasarkan hasil penilaian pada Gambar 4 terkait dengan materi yang disampaikan dapat meningkatkan pengetahuan dan kemampuan peserta, terlihat bahwa dari saluruh responden $42 \%$ mengatakan "sangat setuju" dan 34\% mengatakan "setuju", sehingga apabila dijumlahkan responden yang melakuakn penilaian dengan nilai baik keatas adalah sebesar 
76\% bahwa materi yang disampaikan menurus responden dapat meningktkan pengetahuan dan kemampuan peserta pelatihan.

\section{Hambatan Pelaksanaan Program}

Pada pelaksanaan PKM terdapat beberapa Faktor pendorong yang menjadikan kegiatan ini berjalan diantaranya adalah (1) penerimaan institusi sebagai mitra PKM sangat baik seperti bersedia dengan memberikan keleluasaan dalam pemanfaatan beberapa fasilitas yang dibutuhkan saperti ruangan, akses internet, dan media lainnya sebagai pendukung; (2) Peserta kegiatan memeiliki antusias yang sangat tinggi sehingga materi yng disampaikan mendapatkan respon yang positif. Faktor penghambat kegiatan program yang dilaksanakan adalah khususnya dalam penentuan waktu pelaksanaan program, karena harus disesuaikan dengan agenda sekolah sehingga perlu perencanaan waktu yang tepat agar dapat diikuti oleh seluruh peserta, tetapi secara keseluruhan hal-hal tersebut tidak menghambat secara siginifikan.

\section{KESIMPULAN}

Upaya peningkatan kemampuan dan keterampilan guru dalam melakukan penelitian dan pembuatan artikel ilmiah sebagai bagian dari penilaian dalam kenaikan jabatan fungsional dilakukan dengan mempertimbangkan kebutuhan prioritas utama yang sudah disepakati anatar tim PKM dan mitra dalam hal ini adalah SMKN 2 Kota Tegal. Beberapa kegiatan pelatihan yng dilakukan memberikan manfaat yang signifikan bagi mitra khususnya peserta pelatihan, dengan kegiatan tersebut peserta memiliki peningkatan pengetahuan dan kemampuan dalam membuat sebuat penelitian yang baik dan menulis artikel yang baik pula.

\section{SARAN}

Peningkatan kemampuan dan pengetahuan guru terhadap penelitian dan pembuatan artikel ilmiah perlu sebuah pendampingan yng terus-menru sehingga guru dapat lebih terampil dan memahami terhadap apa yang sedang dilakukan, hal ini menjadikan harus adanya upaya pemberian pendampingan dari semua pihak baik itu sekolah sebagai mitra, maupun dinas diatasnya terkait dengan pengembangan kompetensi guru. Kedepannya perlu ada sebuah model yang tepat dalam mengatasi permasalahan yng dihadapi, seperti adanya pembentukan forum-forum diskusi yang membahasa terkait dengan pengembangan kompetensi dan karir guru khussusnya terkait dengan penbelitian dan pembuatan artikel ilmiah. 


\section{UCAPAN TERIMA KASIH}

Terimakasih disampaikan kepada DRPM RistekDikti yang telah memberikan pendanaan kegiatan melalui program dana hibah skema Program Kemitraan Masyarakat (PKM) tahun anggaran pelaksanaan 2019 dan SMKN 1 Kota Tegal sebagai mitra kegiatan PKM.

\section{DAFTAR PUSTAKA}

[1] Alvarado, L. E. and Bretones, F. D. (2018) 'New working conditions and well-being of elementary teachers in Ecuador', Teaching and Teacher Education, 69, pp. 234-242. doi: 10.1016/j.tate.2017.10.015.

[2] Basrowi, S. and Suwandi, M. (2008) Prosedur Penelitian Tindakan Kelas. Cetakan Pe. Bogor: Penerbit Ghalia Indonesia.

[3] Chrisnanto, Y. H. (2013) 'PENGEMBANGAN SISTEM JURNAL ELEKTRONIK BERBASIS OPEN JOURNAL SYSTEM (OJS)', Aristoteles, 10(2).

[4] Djunaidi, D. (2018) 'Kepemimpinan Kepala Sekolah Dalam Meningkatkan Kinerja Guru', Tarbiyatuna: Jurnal Pendidikan Ilmiah, 2(1), pp. 89-118.

[5] Kamiludin, K. and Suryaman, M. (2017) 'Problematika pada pelaksanaan penilaian pembelajaran Kurikulum 2013', Jurnal Prima Edukasia, 5(1), p. 58. doi: 10.21831/jpe.v5i1.8391.

[6] Ramli, R. and Jalinus, N. (2013) 'Evaluasi kinerja guru sekolah menengah kejuruan Sumatera Barat pascasertifikasi', Jurnal Penelitian dan Evaluasi Pendidikan, 17(1), pp. 72-87. doi: 10.21831/pep.v17i1.1362.

[7] Sanjaya, H. (2010) Penelitian Tindakan Kelas untuk Guru Mata Pelajaran dan Guru Kelas. Jakarta: CV. Trans Info Media.

[8] Sukmawati, C. and Herawan, E. (2017) 'Kepemimpinan Instruksional Kepala Sekolah, Komitmen Guru Dan Mutu Kinerja Mengajar Guru', Jurnal Administrasi Pendidikan, 23(2). 
[9] Susanto, P. (2018) 'Implementasi Model Tutor Guru OK, Jitu, Efektif dan Kreatif (Motor Gojek ) dalam Penulisan Penelitian Tindakan Kelas (PTK) untuk Pengembangan Keprofesian Berkelanjutan (PKB) Guru', METODIK Jurnal Pendidikan Dasar, 1(1), pp. 181-193.

[10] Tanama, Y. J., Bafadal, I. and Degeng, N. S. (2016) 'PENTINGNYA KEPEMIMPINAN PEMBELAJARAN DI SEKOLAH', in Prosiding Seminar Nasional Mahasiswa Kerjasama Direktorat Jenderal Guru dan Tenaga Kependidikan Kemendikbud 2016.

[11] Wahab, A. (2017) 'PUBLIKASI ILMIAH BAGI GURU MADRASAH DALAM MENITI KARIR DAN PRESTASI', Jurnal Media Inovasi Edukasi (JMIE), 3(3), pp. 40-46. 